\title{
A Note on the Text
}

For the Russian text, although the notes and bibliographical references follow the Library of Congress system, a simplified version has been adopted elsewhere, e.g., with the elimination of ' and " to replace the soft and hard signs in Russian as well as with common spellings favored over adherence to the LC system (i.e. with endings in -skii converted to -sky).

Throughout the introductions and notes, the references to Dostoevsky's oeuvre cite the following academic edition of his collected works:

Pss Dostoevskii, F. M. Polnoe sobranie sochinenii v tridtsati tomakh. 30 vols. Leningrad: Nauka, 1972-90.

Unless otherwise cited, much of the information in the notes is gleaned from the research collected in three reference sources on Polish exiles:

Urw Djakow, Włodzimierz, et al. Uczestnicy ruchów wolnościowych w latach 1832-1855 (Królestwo Polskie). Wroclaw: Wydawnictwo Polskiej Akademii Nauk, 1990.

ZPIR Śliwowska, Wiktoria. Zesłancy polscy w Imperium Rosyjskim w pierwszej połowie XIX wieku. Warsaw: Wydawictwo DiG, 1998.

UzS Śliwowska, Wiktoria. Ucieczki z Sybiru. Warsaw: Wydawnictwo Iskry, 2005.

The Russian State Military Historical Archive (RGVIA) gave permission for the reproduction of the two sketches included in this collection: Figure 1 (Fond 349, opis' 27, delo 1381) and Figure 2 (Fond 349, opis' 27, delo 1463). 
